G. Stankevych, Dr. Tech. Science, Professor, E-mail: georgii.stn@ gmail.com https://orcid.org/0000-0002-0583-8174, Researcher ID: F-8557-2016 Yu. Kovra, Postgraduate Student, E-mail: yuriykovra@gmail.com https://orcid.org/0000-0001-6264-6454, Researcher ID: U-2141-2018

A. Kats, PhD Tech. Science, Associate Professor, E-mail: anfisakats20@ gmail.com https://orcid.org/0000-0002-7292-0792, Researcher ID: F-8743-2016

Odessa National Academy of Food Technologies, 112, Kanatna Str., Odessa, 65039, Ukraine

\title{
INFLUENCE OF ELECTROMAGNETIC FIELD OF EXTREMELY LOW FREQUENCIES ON HYGROSCOPIC PROPERTIES OF WHEAT GRAIN MASS
}

\begin{abstract}
The research results of the influence of electromagnetic field (EMF) of extremely low frequencies (ELF) on hygroscopic properties of Shestopalivka wheat variety of 2019 harvest have been given. Grain processing was performed on the experimental stand that consisted of the polymeric cylindrical container for grain, solenoid coil, generator of electromagnetic waves GZ-112/1 and a power amplifier of low frequency. The output signal of generator was set in the form of sine wave and controlled by oscillograph C1-78. The studies were performed at EMF frequencies of 10, 16, 24 and $30 \mathrm{~Hz}$. Magnetic induction of grain treatment was constant and equaled $10 \mathrm{mTl}$. The duration of grain processing was 6 minutes.

The equilibrium moisture content of wheat grain was determined by the tensometric method at temperatures $t 9{ }^{\circ} \mathrm{C}$ and $23{ }^{\circ} \mathrm{C}$ and relative humidity $\varphi 33 \ldots 35 \%$ and $82 \ldots 82.5 \%$. The necessary conditions of air were created in desiccators with solutions of sulfuric acid placed in thermostats and refrigerators.

It has been determined that the equilibrium moisture of wheat grain processed by EMFof ELF - is in the range of $12.17 \ldots 20.56 \%$, and unprocessed grain - in the range of $12.62 \ldots 21.03 \%$. Regardless of the frequency of EMF, equilibrium moisture content of the grain wheat processed by EMF varies according to the known laws - decreases with temperature increase and increases with increasing of air relative humidity. It has been shown that the impact of processing by EMF of ELF on the equilibrium moisture contentof wheat grain is manifested at different frequencies in different ways, which is likely due to the resonance phenomena. It has been established that the processing of grain by EMF with frequencies of $10 . . .30 \mathrm{~Hz}$ practically has no effect on the equilibrium moisture content of grain at $23{ }^{\circ} \mathrm{C}$ and a relative humidity of $33 \ldots 82.5 \%$ which remains practically at the level of the unprocessed grain. It has been shown that the processing of grain by EMF with frequencies of 24 and $30 \mathrm{~Hz}$ under conditions of $t=9{ }^{\circ} \mathrm{C}$ and $\varphi=33 \%$ leads to higher equilibrium moisture content compared to unprocessed wheat grain from $14.45 \%$ to $16.85 \ldots 16.95 \%$. Processing of grain with frequencies of 10 and $16 \mathrm{~Hz}$ under the same conditions, on the contrary - leads to a decrease in the level of equilibrium moisture content to $13.74 \ldots 13.86 \%$. Empirical coefficients have been determined and the equation has been proposed that describes the dependence of equilibrium moisture content of not processed and processed wheat grain by EMF with frequency $10 \ldots 30 \mathrm{~Hz}$ on temperature and relative humidity of the ambient air.
\end{abstract}

Keywords: wheat, hygroscopic properties, sorption isotherms, equilibrium moisture content, processing by electromagnetic fields, extremely low frequencies.

\section{Statement of the problem}

Grain mass has certain characteristics that must be considered in its post-harvest processing and storage. One of these important properties are hygroscopic properties, ie ability to absorb moisture vapours and various gases from the environment, or their desorptionfrom grain into the between grain space. Hygroscopic propertiesof grain are associated with capillary-porous structure and ability of the components that are included in its composition, to absorb and retain water molecules and gas-like components, that leads to continuous change of humidity and smell of grain, which last till achieving of equilibrium condition $[1,2]$.

In the description of the hygroscopic properties of grain, the main concept is the equilibrium moisture the state of dynamic equilibrium, at which partial pressures of water vapor in the air and above the grain are the same. Grain moisture, which corresponds to this state, is called equilibrium moisture [2].

Successful storage of the grain depends on the condition of grain moisture, because the moisture of the grain as a result of sorption of moisture during storage creates conditions to improve the viability of the grain, seeds of various plants, microorganisms and pests of grain that are part of the grain mass. This can lead to spontaneous self-heating of grain, its quality loss, damage or other negative consequences $[1,3]$. Therefore, the study of hygroscopic characteristicsof grain is essential to justify the methods and modes of active ventilation, drying and reliable and proper storage of grain.

The crucial factor that affects the value and rate of achieving equilibrium moisture content is the amount of air relative humidity - the bigger it is, the faster the grain absorbs moisture and the higher the equilibrium moisture content is. The latter depends on the air temperature: the same relative humidity of the air of higher temperature corresponds to a lower equilibrium moisture content and, conversely, lower temperature leads to increase in grain equilibrium moisture. This should be taken into account during daily temperature fluctuations and temperature changes in granaries and the environment $[1,2,3]$.

Different crops under the same conditions 
absorb different amount of moisture, due to construction and biochemical composition of grain. The equilibrium moisture content of individual grains in the grain mass is also different. It is well known that the reasons of uneven distribution of moisture in the grain mass can be:

- uneven distribution of moisture in each individual grain;

- different sorption capacity of grains of different fullness and size;

- relative humidity of the ambient grain mass;

- release of water and heat by all living components of the grain mass;

- condition of granaries;

- change in temperature in different parts of the grain embankment and the associated phenomenon of thermal and moisture conductivity [1].

There is some evidence that testifies to the influence of energy of electrophysical nature on water molecules, in particular, the influence of the electromagnetic field (EMF) [4-8]. Processes of influence of EMF of microwave range on water and wet materials have been studied for a long time and are used in everyday life and in agriculture in the processes of disinfection and drying [7-9].

Recently, increased attention has been given to study of the processes of EMF nonthermal impact on the biological objects, there are some recommendations concerning their use in agriculture. At the same time the impact of EMF range of ELF on the processes of moisture transfer in grains that are interesting in terms of their use in post harvest processing and storage of grain hasn't been studied yet.

The above mentioned provides a basis for the study of processes occurring in the grain after its processingt with EMF of ELF. Starting point for this is a study of its hygroscopic properties, including equilibrium moisture content, which is important in postharvest processing and storage of grain mass. It was the reason that determined the purpose of this study.

\section{The purpose and objectives of the study}

The purpose of the study was to elucidate the patterns of the changes of hygroscopic properties of wheat grain processed by EMF of ELF depending on the temperature and the relative humidity of the outside air, that will allow to increase effectiveness of its postharvest processing and storage.

\section{Materials and methods of the research}

The research was conducted on grain wheat variety Shestopalivka of 2019 crop, grown in Odessa region.

Grain processing by EMF of ELF. The processing of wheat was carried out on the experimental stand that consists of a polymer cylindrical tube (container for grain), solenoid coil, generator of electromagnetic waves GZ-112/1 and low frequency power amplifier. The output signal of the generator was set in the form of a sine wave and controlled by an oscillograph C1-78.

The studies were performed at frequencies of $v$ EMF 10, 16, 24 and $30 \mathrm{~Hz}$. The magnetic induction of grain processing was constant and equaled to $10 \mathrm{mTl}$.
The required values of the current in the experimental stand for maintenance of the given magnetic induction amounted to $1 \mathrm{~A}$. To do this, before each experiment on grain processing a power amplifier controller of low frequences set the required value of current strength, which was controlled by universal digital voltmeter B738.

The duration of grain processing was $\tau=6$ minutes, which was justified on the basis of the results of previous studies of the effect of EMF of ELF on the physiological properties of grain.

Determination of Equilibrium moisture content of the grain. The research was conducted by a generally accepted tensometric method, which is that the grain samples are placed in the glass containers that are placed in hygrostat- desiccator with liquid that has a certain elasticity of water vapor above the surface. By weighing the containers within a certain period of time we judge the degree of moisture absorption by the grain.

The experiments were performed in the range of air temperatures $\mathrm{t}=9 \ldots .23^{\circ} \mathrm{C}$ and its relative humidity $\varphi=33 \ldots 82.5 \%$, which simulate the conditions of active ventilation and storage of grain at different times of the year.

To ensure the adopted for the research temperatures of the environment, two desiccators, in which relative humidity was created as $33 \%$ and $82 \%$, were placed in a refrigerator with a temperature of $9{ }^{\circ} \mathrm{C}$, the other two, in which a relative humidity was $35 \%$ and $82.5 \%$ were placed in a thermostat with the temperature of $23{ }^{\circ} \mathrm{C}$. In every desiccator containers with grain samples weighing about $5 \mathrm{~g}$ were placed. The research was conducted in two parallels.

To create a certain relative humidity, about $1 . . .2 \mathrm{dm} 3$ of sulfuric acid of the necessary density was poured in the desiccator, which provided the above values of relative humidity $(33 \%, 35 \%$ and $82 \%$ and $82,5 \%$ ). In this case, to ensure more accurate results, the concentration of solutions of sulfuric acid, desiccators were prepared taking into account the dependence of its density on temperature [10]. The density of sulfuric acid and its solutions was monitored using a set of hydrometers.

According to the obtained data of the change in the mass of grain samples in the boxes at each specific point the intermediate (current) grain moisture was calculated according to the formula

$$
w_{i}=100-\frac{m_{0}}{m_{i}}\left(100-w_{0}\right)
$$

where $\mathrm{w}_{\mathrm{i}}$ - intermediate (current) grain moisture at the $\mathrm{i}$-th time, $\%$;

$\mathrm{m}_{0}$ - initial mass of the grain sample (at the beginning of the experiment ), $\mathrm{g}$;

$\mathrm{m}_{\mathrm{i}}$ - the intermediate (current) mass of the grain in the $\mathrm{i}$-th moment of time, $\mathrm{g}$;

$\mathrm{w}_{0}$ - initial grain moisture, $\%$

For each moment of time on the basis of the two parallels values of equilibrium moisture an average value was calculated. After achieving a sustainable weight of samples,the experiment was stopped and with the help of calculation and the experimental method the achieved moisture was determined that was taken as equilibrium 
moisture.

The initial and final grain moisture in the experiments were determined according to DSTU GOST 29144: 2009 (ISO 711-85) Grain and grain products. Determination of moisture (a basic control method). [Legally valid since 2009-12-01]. Moisture values obtained for further processing of the data were recalculated to find out the moisture content (Moisture on dry weight). Further generalization of the experimental data was performed by statistical methods using spreadsheet MS Excel 2007.

To increase the accuracy of the equilibrium moisture content of grain, the obtained values of equilibrium moisture in two parallels were generalized by an approximate equation

$$
\mathrm{w}_{\mathrm{i}}=\mathrm{w}_{0}+\tau_{\mathrm{i}} /\left(\mathrm{a}+\mathrm{b}_{\tau \mathrm{i}}\right),
$$

where $\tau_{\mathrm{i}}$ - is the duration of the experiment from the beginning of the experiment to the weighing of the ith sample, a day;

$\mathrm{a}, \mathrm{b}$ - empirical coefficients determined on the basis of the experimental data by the method of least squares.

\section{Research results and their discussion}

According to the research methodology, 20 experiments were performed, including 4 experiments with unprocessed grain and 4 experiments with grain processed by EMF of ELF at frequencies of 10, 16, 24 and $30 \mathrm{~Hz}$. In total, equilibrium moisture content was determined in 40 containers. Initial moisture of wheat grain (moisture for a grain mass) amounted to $11.00 \%$ which corresponds to moisture content (moisture for a dry mass) $-12.35 \%$.

After the experiments, their mathematical processing was carried out. Thus in parallel experiments the average values of grain mass in the containers at each selected time was calculated, which then was recalculated into current estimated grain moisture.

The experimental values of the current moisture for averaging were approximated by empirical equations of sorption or desorption isotherms, the coefficients of which were determined by least squares. According to the sorption isotherms, equilibrium moisture content of wheat for each temperature value and relative humidity $\varphi$ of air in the desiccators was determined. The given experiments showed that duration from air parameters was within $20 . . .60$ days.

As an example, fig. 1 shows the sorption curves of moisture for the wheat that was processed by EMF with $16 \mathrm{~Hz}$ frequencyof grain wheat that was placed in a desiccator at the temperature of $23{ }^{\circ} \mathrm{C}$ and relative moisture of $35 \%$. On the schedule we can see the experimental dots of the two parallels (experiment 1, experiment 2) and generalizing sorption curve (calculated) that is obtained by the equation given in the methodology. We can also see a good convergence of the experimental values of the current moisture in the 1 st and 2nd parallels at all points of the experiments. We can also see that on the 45th day the equilibrium moisture content of wheat grain was $12.73 \%$. Similarly moisture content was determined for all experiments that were carried out.

The resulting calculated values of equilibrium moisture content of wheat we further was compared with achieved ultimate moisture of wheat samples under every investigated condition (in each desiccator). The obtained in such a way values of equilibrium moisture content are shown in Table 1 . The same table shows the conditions of each experiment - temperature $t$ and relative humidity $\varphi$, as well as the frequency $v$ of EMF of ELF.

The data in the table shows that the equilibrium moisture content of unprocessed Shestopalivka wheat in the investigated temperature range $\mathrm{t}=9 . .23{ }^{\circ} \mathrm{C}$ and relative humidity $\varphi=33 \ldots 82.5 \%$ is $\mathrm{w}_{\mathrm{e}}=12.62 \ldots 21.03 \%$, and the processed by EMF of ELF is in the range $12.17 \ldots 20.56 \%$. Processing of grain by EMF at frequencies in the range of $10 \ldots 30 \mathrm{~Hz}$ changes under the same conditions the values of the equilibrium moisture content.

It is known from literature sources [2] that grain sorption isotherms can be described quite accurately by the following equation

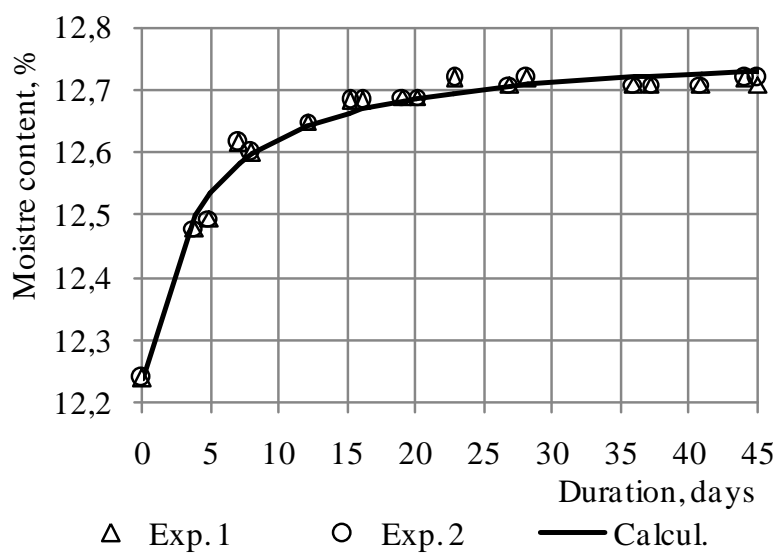

Fig. 1 - The sorption curve of the wheat grain processed by EMF with frequency of $16 \mathrm{~Hz}$ under the temperature of $23^{\circ} \mathrm{C}$ and air relative humidity of $35 \%$

Table 1 - Conditions and results of the experiments

\begin{tabular}{||c||c||c||c||}
\hline \multicolumn{2}{|c||}{ Experimental conditions } & \multirow{2}{*}{$\begin{array}{c}\text { Equilibrium } \\
\text { moisture content }\end{array}$} \\
\hline \hline $\mathrm{t},{ }^{\circ} \mathrm{C}$ & $\varphi, \%$ & v, Hz & 16.54 \\
923 & 82.5 & u.p. & 21.03 \\
23 & 82 & u.p. & 12.62 \\
9 & 35 & u.p. & 14.45 \\
\hline \hline 23 & 33 & u.p. & 16.84 \\
9 & 82.5 & 10 & 18.84 \\
23 & 82 & 10 & 13.10 \\
9 & 35 & 10 & 13.74 \\
\hline \hline 23 & 33 & 10 & 16.73 \\
9 & 82.5 & 16 & 19.90 \\
23 & 82 & 16 & 12.73 \\
9 & 35 & 16 & 13.86 \\
\hline \hline 23 & 33 & 16 & 16.95 \\
9 & 82.5 & 24 & 20.56 \\
23 & 82 & 24 & 13.06 \\
9 & 35 & 24 & 15.86 \\
\hline \hline 23 & 33 & 24 & 16.89 \\
9 & 82.5 & 30 & 17.50 \\
23 & 82 & 30 & 12.17 \\
9 & 35 & 30 & 16.26 \\
\hline
\end{tabular}

Note: u.p. - unprocessed 


$$
w_{\mathrm{e}}=A-B \cdot t+(C-D \cdot t)\left[\lg \left(\frac{1}{1-\varphi}\right)\right]^{0,5}
$$
grain, $\%$

where $\mathrm{w}_{\mathrm{e}}-$ equilibrium moisture content of

A, B, C, D - are stable that depend on the form of connection of moisture with the dry matter of the grain and the temperature of the grain;

$\varphi$ - air relative humidity, in fractions.

The values of stable A, B, C, D are determined based on the experimental data by the method of least squares. For practical implementation of the method of least squares we can usually use the procedure "Search of the solutions" of the spreadsheet MS Excel.

Using the above mentioned dependence (3) at the final stage of processing of the experimental data on the hygroscopic properties of the investigated wheat grain samples, the empirical coefficients A, B, C, D were determined, the values of which under different experimental conditions are given in table. 2. Given that the values of the four coefficients were determined based on the average results of four experiments, the calculated (according to the equation 3) values of equilibrium moisture content exactly coincide with the the experimental data.

Table 2 - Values of empirical coefficients A, B, C, D in the equations of equilibrium moisture content isotherms of unprocessed and processed by EMF wheat grain

\begin{tabular}{||c||c||c||c||c||}
\hline Frequency v, Hz & A & B & C & D \\
\hline \hline u. p. & 8.0111 & -0.0319 & 18.4856 & 0.4141 \\
10 & 8.6786 & -0.0313 & 13.3138 & 0.2069 \\
16 & 7.8547 & -0.0400 & 16.3643 & 0.3137 \\
24 & 12.8976 & 0.1605 & 11.6209 & 0.1183 \\
30 & 19.9846 & 0.5430 & -2.3617 & -0.5722 \\
\hline
\end{tabular}

Note: u.p. - unprocessed

According to the empirical equations the isotherms of calculated equilibrium moisture content of unprocessed and processed wheat grain with different frequencies of EMF were built. For example, Fig. 2 shows isotherms of equilibrium moisture content of wheat at temperatures of 9,15 and $23{ }^{\circ} \mathrm{C}$ of unprocessed (a) and processed by EMF with frequency of $10 \mathrm{~Hz}$ (b) wheat grain, which give a visual representation of the change in equilibrium moisture depending on air relative humidity. We can see that the processed with $10 \mathrm{~Hz}$ frequency grain of wheat in the investigated temperature range has a narrower range of values of equilibrium moisture content. In addition, the value of $\mathrm{w}_{\mathrm{e}}$ under the temperature of $9{ }^{\circ} \mathrm{C}$ are lower than in the unprocessed wheat. At the temperature of $23{ }^{\circ} \mathrm{C}$ on the contrary, the equilibrium moisture content of grain in the range of $\varphi=30 \ldots 90 \%$ is higher than in unprocessed grain that confirms certain effect of EMF on the hygroscopic properties of the investigated wheat grain.

Summary comparative characteristics of the values of equilibrium moisture content of the processed at frequencies of $10 \ldots 30 \mathrm{~Hz}$ wheat grain depending on the temperature and relative humidity are shown in Fig. 3.

The analysis of the histograms given in fig. 3 shows that regardless of the frequency of EMF, equilibrium moisture content of the wheat processed by EMF varies according to the known laws - decreases with increasing air temperature and increases with increasing air relative humidity $\varphi$, which is characteristic of colloidal capillary and layered bodies which include grain. But it can be noted that under air temperature of $9{ }^{\circ} \mathrm{C}$ with change of $\varphi$ from $33 \%$ to $82 \%$ equilibrium moisture content achieves the largest values in the unprocessed wheat $(21.03 \%)$. The grain processed by EMF we for $\varphi=82 \%$ has smaller values, which are in the range of $17.50 \ldots 20.56 \%$, and the lowest value is reached at a frequency of $30 \mathrm{~Hz}$, which is much less than in the unprocessed grain - by $3.53 \%$. From a practical point of view, the relative moisture of $82 \%$ and air temperature of $+9{ }^{\circ} \mathrm{C}$ are typical for the autumn-winter period of grain storage, and the fact is that EMF processing with a frequency of $30 \mathrm{~Hz}$ will contribute to less moisture in the grain during its storage in these adverse conditions.

You may also notice that the processing of grain by EMF with frequencies of $10 \ldots 30 \mathrm{~Hz}$ virtually has no effect on equuilibrium moisture content of grain at $23{ }^{\circ} \mathrm{C}$ and a relative humidity of $35 \ldots 82.5 \%$, which practically remains at the level of the unprocessed grain.

It is noteworthy that the processing of grain by EMF with frequencies of $24 \mathrm{~Hz}$ and $30 \mathrm{~Hz}$ at $\mathrm{t}=9^{\circ} \mathrm{C}$ and $\varphi=33 \%$ leads to an increase in equilibrium moisture content in wheat compared to unprocessed grain from $14.45 \%$ to $16.85 \ldots 16.95 \%$. Processing of the grain

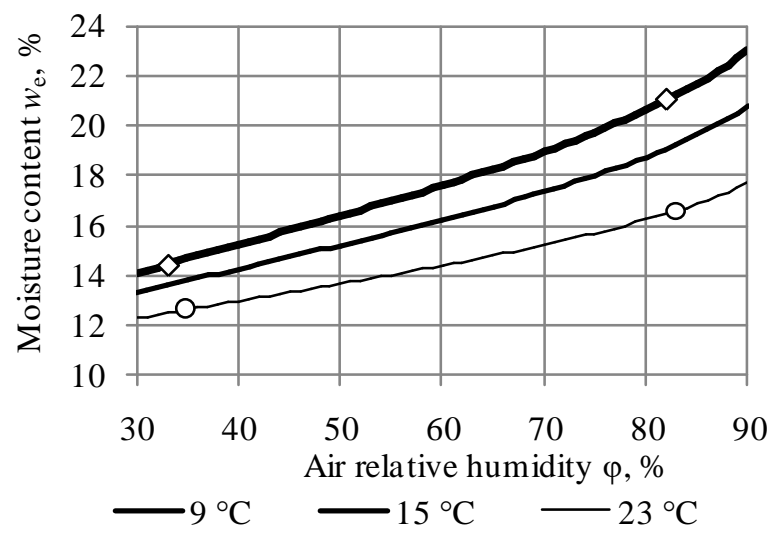

a) unprocessed grain

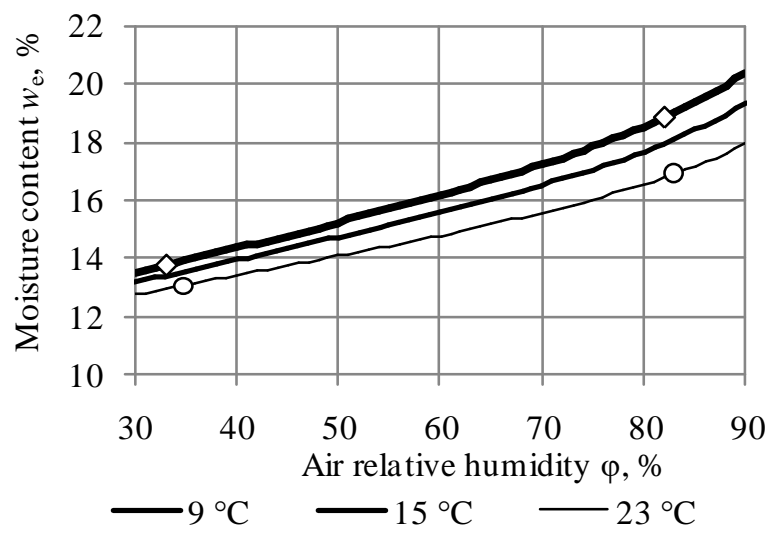

b) grain processed by EMF with frequency of $10 \mathrm{~Hz}$

Fig. 2 - Isotherms of equilibrium moisture content of unprocessed and processed by EMF of ELF wheat grain 


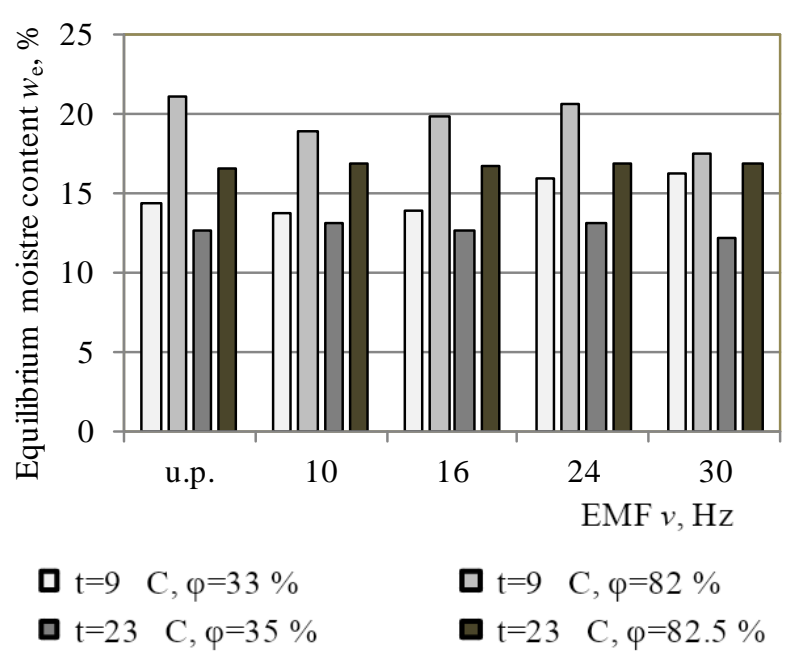

Fig. 3 - Influence of EMF of ELF frequency on equilibrium moisture content of grain wheat we depending on temperature $t$ and relative humidity $\varphi$ of the surrounding air

with frequencies of $10 \mathrm{~Hz}$ and $16 \mathrm{~Hz}$ under the same conditions, on the contrary - leads to reducing of the equilibrium moisture content of up to $13.74 \ldots 13.86 \%$.

Thus, continuation of the research on processing of wheat grain by EMF of ELF will allow purposefully influence the level of the equilibrium moisture content, changing it to rational limits in terms of its post harvest processing (active ventilation) and reliable and proper storage.

\section{Conclusions}

Numerous values of equilibrium moisture content of Shestopalivka wheat variety of 2019 harvest at temperatures of $9 \ldots 23{ }^{\circ} \mathrm{C}$ and air relative moisture of $33 . .82 .5 \%$ were determined. It has been shown that the equilibrium moisture of the wheat grain, processed by
EMF of ELF stays within $12.17 \ldots 20.56 \%$, and in the unprocessed grain - within $12.62 \ldots 21.03 \%$.

It has been shown that the impact of processing by EMF of ELF on equilibrium moisture content of wheat grain is developed at different frequencies in different ways, which is likely due to the resonance phenomena. Regardless of the frequencyof EMF, equilibrium moisture content of wheat grain processed by EMF changes due to the known laws - decreases with air increasing temperature $t$ and increases with increasing air relative humidity $\varphi$, which is characteristic for colloidal capillary-layered bodies to which grain refers. It has been shown that the impact of processing by EMF of ELF on the equilibrium moisture content of wheat grain is developed at different frequencies in different ways, which was probably due to the resonance phenomena.

It has been established that the processing of grain by EMF with frequencies of $10 \ldots 30 \mathrm{~Hz}$ virtually has no effect on the equilibrium moisture content of grain at $23{ }^{\circ} \mathrm{C}$ and a relative humidity of $35 \ldots 82.5 \%$, which practically stays at the same level with that of unprocessed grain. It has been shown that processing of grain by EMF of ELF with frequencies of $24 \mathrm{~Hz}$ and $30 \mathrm{~Hz}$ under conditions of $\mathrm{t}=9^{\circ} \mathrm{C}$ and $\varphi=33 \%$ leads to increase in equilibrium moisture content of wheat compared to unprocessed grain from $14.45 \%$ to $16.85 \ldots 16.95 \%$. Processing of the grain with frequencies of $10 \mathrm{~Hz}$ and $16 \mathrm{~Hz}$ under the same conditions, on the contrary - leads to lower equilibrium moisture content up to $13.86 \ldots 13.74 \%$.

Empirical coefficients have been determined and the equation describing the dependence of equilibrium moisture content of unprocessed and processed by EMF Shestopalivka variety wheat grain with frequencies of $10 \ldots 30 \mathrm{~Hz}$ on the temperature and the relative humidity of the surrounding air, has been offered.

\section{REFERENCES}

1. Puzik L. M. Tekhnolohiia zberihannia i pererobky zerna : navch. posib. / L. M. Puzik, V. K. Puzik; [Khark. nats. ahrar. unt im. V. V. Dokuchaieva]. Kh.: KhNAU, 2013. 312 s.

2. Ginzburg A. S. Massoobmennyie harakteristiki pischevyih produktov / A.S. Ginzburg, I.S. Savina. M.: Legkaya i pischevaya prom-st, 1982. - $280 \mathrm{~s}$.

3. Podpriatov H. I. Zberihannia i pererobka produktsii roslynnytstva : navch. posib. / H. I. Podpriatov, L. F. Skaletska, A. M. Senkov, V. S. Khylevych. K. : Meta, 2002. 495 s.

4. Kasyanov G. I. Obrabotka selskohozyaystvennogo syirya elektromagnitnyim polem nizkoy chastotyi. Teoriya i praktika: Monografiya. / G.I. Kasyanov, M.G. Baryishev, R.S. Reshetova, V.T. Hristyuk. -SPb.: Troitskiy most, 2016. - 296 s. URL: http://e.lanbook.com/book/90693.

5. Patent RF \# 2364075 MPK A01F 25/00 (2006.01). Sposob hraneniya zernovyih kultur / Kulik K.S., Martyanov S.N., \# 2008107181/12, zayavl. 28.08.2008, opubl. 20.08.2009. Byul. \# 23.

6. Zhalvin E.V., Shibryaeva L.S., Sadyikov Zh.S. Nizkochastotnoe elektromagnitnoe obluchenie zerna v zer-nouborochnom kombayne // Selskohozyaystvennyie mashinyi i tehnologii, \# 2, 2016 S. 16-21.

7. Boshkova Y.L. Prymenenye mykrovolnovoho metoda obrabotky rastytelnblkh materyalov v razlychnblkh tekhnolohyiakh. monohrafyia / Y.L. Boshkova, N.V. Volhusheva. Odessa. Bondarenko M.A. 2017. 224 s.Podpryatov H.I, Skalets'ka L.F., Sen'kov A.M., Khylevych V.S. (2002). Zberihannya i pererobka produktsiyi roslynnytstva : navch. posib., K. : Meta, 495 p.

8. Samonin V.V., Podvyaznikov M. L., SHevkina A. YU., \& Tarasova A. A. Vliyanie elektromagnitnogo polya na process sorbcii parov vody na silikagele. Sankt Peterburgskij gosudarstvennyj tekhnologicheskij institut (tekhnicheskij universitet), $6(32), 2009.57-59$ s.

9. Ospanov A.B., Vasil'ev A.N., Budnikov D.A., Karmanov D.K., Vasil'ev A.A., Bajmuratov D.SH., Toksan-baeva B.O., SHalginbaev D.B. Sovershenstvovanie processov sushki i obezzarazhivanie zerna v SVCH pole. Monog-rafiya. Almaty: Nur-Print, 2017. 163 s.

10. Postoyannaya otnositelnaya vlazhnost nad nasyischennyimi rastvorami soley $v$ zavisimosti ot tempera-turyi, a takzhe glitserina $i$ sernoy kislotyi $v$ zavisimosti ot temperaturyi $i$ kontsentratsii. $-U R L$ : http://tehtab.ru/Guide/GuidePhysics/Humidity/SaturatedSaltSolutionsHumidity/ 
Г.М. Станкевич, д-р техн. наук, професор, E-mail: georgii.stn@ gmail.com https://orcid.org/0000-0002-0583-8174, Researcher ID: F-8557-2016

Ю.В. Ковра, аспірант, E-mail: yuriykovra@gmail.com https://orcid.org/0000-0001-6264-6454, Researcher ID: U-2141-2018

А.К. Кац, канд. техн. наук, доцент, E-mail: anfisakats20@ gmail.com https://orcid.org/0000-0002-7292-0792, Researcher ID: F-8743-2016

\title{
ВПЛИВ ЕЛЕКТРОМАГНІТНОГО ПОЛЯ ВКРАЙ НИЗЬКИХ ЧАСТОТ НА ГІГРОСКОПІЧНІ ВЛАСТИВОСТІ ЗЕРНОВОЇ МАСИ ПШЕНЦІ
}

\begin{abstract}
Анотація
Наведено результати дослідження впливу електромагнітного поля (ЕМП) вкрай низьких частот (ВНЧ) на гігроскопічні властивості зерна пшеничі сорту Шестопалівка 2019 року врожаю.

Обробку зерна проводили на експериментальному стенді, який складався з полімерної ииліндричної ємності для зерна, соленоїдної котушки, генератора електромагнітних коливань ГЗ-112/1 та підсилювача потужності низької частоти. Вихідний сигнал генератора задавали у формі синусоїди та контролювали осиилографом С1-78. Дослідження проводили за частот ЕМП 10, 16, 24 та 30 Ги.. Магнітна індукиія обробки зерна була сталою та дорівнювала 10 мТл. Тривалість обробки зерна становила 6 хв.

Рівноважний вологовміст зерна пшениці визначали тензиметричним методом за температур $t 9{ }^{\circ} \mathrm{C} i 23{ }^{\circ} \mathrm{C}$ та відносної вологості повітря $\varphi 33 \ldots 35 \%$ і $82 \ldots 82,5 \%$. Необхідні умови повітря створювали у ексикаторах з розчинами сірчаної кислоти, розміщених у термостатах та холодильниках.

Визначено, щуо рівноважна вологість обробленого ЕМП ВНЧ зерна пшениці знаходиться в межах 12,17...20,56\%, а не обробленого зерна - в межах 12,62...21,03\%. Незалежно від частоти ЕМП рівноважний вологовміст обробленого ЕМП зерна пшениці змінюсться за відомими закономірностями - зменшується при зростанні температури та збільшується при зростанні відносної вологості повітря. Показано, що вплив обробки ЕМП ВНЧ на рівноважний вологовміст зерна пшенииі проявлясться за різних частот по різному, що вірогідно пов'язано з резонансними явищами. Встановлено, щзо обробка зерна ЕМП з частотами $10 \ldots 30$ Ги практичне не впливає на рівноважний вологовміст зерна за температури $23{ }^{\circ} \mathrm{C}$ i відносної вологості $35 \ldots 82,5 \%$, який залишається практично на рівні не обробленого зерна. Показано, шо обробка зерна ЕМП з частотами $24 \mathrm{ma} 30$ Ги за умов $t=9{ }^{\circ} \mathrm{C}$ i $\varphi=33 \%$ призводить до підвищення рівноважсного вологовмісту пшениці порівняно з необробленим зерном з 14,45 \% до 16,85...16,95\%. Обробка зерна з частотами 10 та 16 Ги за тих же умов, навпаки - призводить до зниження рівноважного вологовмісту до 13,74...13,86 \%. Визначено емпіричні коефіцієнти та запропоноване рівняння, яке описує залежність рівноважного вологовмісту не обробленого та обробленого ЕМП за частот 10...30 Ги дослідженого зерна пшениці від температури та відносної вологості навколишнього повітря.
\end{abstract}

Ключові слова: зерно пшениці, гігроскопічні властивості, ізотерми сорбції, рівноважний вологовміст, обробка електромагнітним полем, вкрай низькі частоти.

\section{ЛІТЕРАТУРА}

1. Пузік Л. М. Технологія зберігання і переробки зерна : навч. посіб. / Л. М. Пузік, В. К. Пузік ; [Харк. наи. аграр. ун-т ім. В. В. Докучаєва]. Х.: ХНАУ, 2013. 312 c.

2. Гинзбург А. С. Массообменные характеристики пищевых продуктов / А.С. Гинзбург, И.С. Савина. М.: Легкая и пищевая пром-сть, 1982. - $280 \mathrm{c}$.

3. Подпрятов Г. І. Зберігання і переробка продукиї рослинництвва: навч. посіб. / Г. І. Подпрятов, Л. Ф. Скалецька, А. М. Сеньков, В. С. Хилевич. К. : Мета, 2002. 495 с.

4. Касьянов Г. И. Обработка сельскохозяйственного сырья электромагнитным полем низкой частоты. Теория и практика: Монография. / Г.И. Касьянов, М.Г. Барышев, Р.С. Решетова, В.Т. Христюк. -СПб.: Троиикий мост, 2016. - 296 с. URL: http://e.lanbook.com/book/90693

5. Патент РФ № 2364075 МПК АО1F 25/00 (2006.01). Способ хранения зерновых культур / Кулик К.С., Мартьянов С.Н., № 2008107181/12, заявл. 28.08.2008, опубл. 20.08.2009. Бюл. № 23.

6. алвин Э.В., Шибряева Л.С., Садыков Ж.С. Низкочастотное электромагнитное облучение зерна в зерноуборочном комбайне // Сельскохозяйственные машины и технологии, № 2, 2016 C. 16-21.

7. Бошкова И.Л. Применение микроволнового метода обработки растительных материалов в различных технологиях. монография / И.Л. Бошкова, Н.В. Волгушева. Одесса. Бондаренко М.А. 2017. 224 с.

8. Самонин В.В., Подвязников М. Л., Шевкина А. Ю. \& Тарасова А. А. Влияние электромагнитного поля на проиесс сорбиии паров воды на силикагеле. Санкт Петербургский государственный технологический институт (технический универсиmem), 6 (32), 2009. 57-59 c.

9. Оспанов А.Б., Васильев А.Н., Будников Д.А., Карманов Д.К., Васильев А.А., Баймуратов Д.Ш., Токсанбаева Б.О., Шалгинбаев Д.Б. Совершенствование процессов сушки и обеззараживание зерна в СВЧ поле. Монография. Алматы: Нур-Принт, 2017. $163 c$

10. Постоянная относительная влажность над насыщенными растворами солей в зависимости от температуры, а также глицерина и серной кислоты в зависимости от температуры и концентрации. - URL: http://tehtab.ru/Guide/GuidePhysics/ Humidity/SaturatedSaltSolutionsHumidity/

Received 18.01.2021

Reviewed 02.02.2021

Revised 22.02.2021

Approved 30.03.2021

Cite as Vancouver Citation Style

Stankevych G., Kovra Yu., Kats A. Influence of electromagnetic field of extremely low frequencies on hygroscopic properties of wheat grain mass.

Grain products and mixed fodder's, 2021; $21(1,81)$ : 9-14. DOI https://doi.org/

Cite as State Standard of Ukraine 8302:2015

Influence of electromagnetic field of extremely low frequencies on hygroscopic properties of wheat grain mass. / Stankevych G. et al. // Grain Products and Mixed Fodder's. 2021. Vol. 21, Issue 1 (81). P. 9-14. DOI https://doi.org/ 